\title{
Activist as Symptom: Healing Trauma within a Ruptured Collective
}

\author{
Sara Granovetter | ORCID: 0000-0001-6026-6116 \\ California Institute of Integral Studies; East West Psychology, \\ San Francisco, CA, USA \\ granovet@post.harvard.edu
}

\begin{abstract}
Animal activists serve as symptom-bearers for trans-species collective trauma within Western-industrial society. Findings from literature on traumatology and nonhuman animal activism, contemporary discourse, and the voices of ten activists currently in the field suggest that many animal activists suffer some form of trauma. Activist trauma arises through overlapping, complex relational processes of intersubjective attunement with nonhuman animals and embeddedness within a human social context that disavows nonhuman suffering. In understanding activist trauma as a symptom of a dysfunctional system, I depathologize activist suffering and view activists as integral members of a whole society that seeks healing.
\end{abstract}

\section{Keywords}

trans-species psychology - PTSD - collective trauma - animal activism - bearing witness - slaughterhouse vigil - open rescue - limbic resonance

There is a growing movement of human animals who choose to bear witness to what most individuals assiduously avoid: socially and legally sanctioned suffering of nonhuman animals, in particular, those on farms who are harmed and killed en masse each day. Institutions that implement this harm are veiled from the public eye (Pachirat, 2011). Using windowless buildings and other obfuscating methods, owners of industrial farms and slaughterhouses go to great lengths to hide their activities. 
A combination of physical and linguistic masking creates a veritable wall of secrecy concealing various stages of nonhuman suffering, death, and processing for human use. Animal advocates who stage direct actions (e.g., investigative undercover work, slaughterhouse vigils) breach this veil for the purpose of revealing the plight of animals on farms. Frontline activists commit these acts for a variety of reasons: to bring a compassionate gaze where there is none, to speak for animals who are "voiceless" in the eyes of the general public, to go beyond words to commit their bodies to their beliefs, and, in some cases, to rescue victims.

While a growing literature attests to the psychological effects of slaughterhouse workers' exposure to and perpetration of violent deaths of animals on farms (Dillard, 2008; Pachirat, 2011; Porcher, 2011), I here emphasize the less commonly studied group of animal activists. Participating activists are exposed to an overwhelming degree of nonhuman suffering. Prior to these encounters, most advocates have not been exposed to mass violence and death. The experiences are, therefore, extraordinary and, as a growing yet still limited literature documents, are accompanied by serious psychological impacts.

Drawing from a convergence of literature on traumatology and animal activism, contemporary discourse, and the voices of ten activists currently in the field, I explore the nature of this trans-species trauma from a psychosocial perspective. First-person narratives from interviewed activists provide living, active voices that speak to what has been documented in the literature and predicted from the fields of traumatology and psychology. The goal of this article is to examine psychological suffering at the intersection of human and nonhuman animals as a social and existential phenomena indicative of radical cultural change.

By definition, animal activists are embedded within an intersubjective, relational web, a web that situates them in dynamic tension between nonhuman animals and the traumatogenic societal framework in which these nonhuman animals are harmed. While activist trauma is experienced by individuals, it is embedded in a much broader, collective terrain. From this view, activist psychological suffering is a symptom of trans-species cultural trauma, a multi-species collective experience of suffering generated by disconnection, disassociation, and violence across species boundaries.

By understanding activist trauma as a symptom of much vaster collective trauma, and indicative of paradigmatic change, I depathologize the stereotypic characterization of animal activists as angry extremists and instead view them as integral voices within a system in search of healing. Critically, this frame dispels the image of animal activists as social isolates by including perpetrators, 
bystanders, and the avoidant public who, while largely silent, nonetheless, play key roles in a psychosocial drama. This greater inclusivity problematizes narratives that frame vegans and activists as outside of and other than mainstream society in their vulnerability to trauma related to nonhuman suffering. In this light, activists emerge as vital symptoms of the collective in which they are embedded, where their trauma is reflective of the covert seeking to become overt in order to heal.

\section{Nonhuman Animal Activism and Its Perils}

As appreciation for animal sentience and psychological vulnerability has increased, there has been concomitant sympathy for humans who commit their time and wellness to disabling perceptions and actions which cause undue nonhuman suffering. Given greater exposure through media and participation in slaughterhouse vigils, open rescues, and undercover investigations of factory farms or slaughterhouses, there is also greater exposure to chronic stress, interpersonal conflict, and trauma for those activists who respond to violence against animals (Bradshaw, 2019).

Within this study, I define animal activists as those individuals who engage in direct contact with animals being harmed or killed. This narrow definition is intended to bring focus to a particular set of experiences, while also acknowledging other important forms of animal advocacy that are beyond the scope of this article. Notably, Bryant (2006) contends that even for those who do not bear witness to animal suffering and death, trauma is inherent in animal advocacy work: "Despite differences in subject matter and type of advocacy, all of these advocates deal with knowledge of massive suffering ... these advocates' claims are generally dismissed by most of society" (p. 67). The present study has, therefore, potential implications for all animal advocates.

Semi-structured interviews of ten activists from four nonprofit advocacy groups - DxE, Vegans of the Bay, Global SAVE, and In Defense of Animals were conducted. This outreach recruited participants who identified as suffering distress as a result of their advocacy activities, including, but not limited to, the direct witnessing of animal suffering and death within the context of the farming industry. All interviewed activists participated in at least one of the following: a slaughterhouse vigil through the Global SAVE movement, an open rescue, or an undercover investigation of a slaughterhouse or factory farm. Three out of ten of the interviewed activists regularly participate in all three activities. To preserve anonymity, individual activists are cited using the code $\mathrm{P}(\mathrm{n})$, where $\mathrm{P}=$ Participant and $\mathrm{n}$ = identifying number. 
Founded by Anita Krajnc, the Global SAVE movement consists of over six hundred groups around the world dedicated to raising awareness about the suffering of chickens, cows, and pigs on factory farms. At their vigils, participants "bear witness to animals in their final moment as they approach slaughterhouses" (Lockwood, 2018; Bradshaw, 2019). Open rescues are forms of direct actions where activists rescue injured or sick animals from farms or institutional settings. Rather than hide their identities, activists taking part in open rescues do so transparently and often publicize efforts $\left(\mathrm{P}_{3}\right)$. Conversely, undercover investigations involve gaining clandestine access to factory farms or slaughterhouses for the purpose of revealing conditions to proper authorities or to the public $\left(\mathrm{P}_{5}\right)$.

One area of emerging scholarship examines the psychosocial wellbeing of vegans, animal care workers, and animal activists (Bradshaw, Borchers, \& Muller-Paisner, 2012; Rank, Zaparanick, \& Gentry, 2009), as well as emphasizes the influence of a dysfunctional social context on these individuals' states of wellness (Joy, 2018; Mann, 2018). Bradshaw et al. (2012) explore issues of wellbeing, compassion fatigue, and trans-species identity among workers, with attention on the link between animal care professional functioning and the wellness of their nonhuman charges. In this exploration, she notes that the lack of resources and social support for animal care workers leads to vulnerability to trauma or post-traumatic stress disorder (PTSD) and argues for the infusion of trauma-informed care training in animal rescues and sanctuaries.

Activists encountering ecological degradation and injustices against animals face unique trauma, resulting in novel terminology to describe the adverse effects. Jones (2007) identifies earth and animal activists as "a category of activists who are at particular risk of trauma" and identifies these forms of activism as ones that entail "inherent physical and emotional risks" (p. 19). She coined the term "aftershock" to give language to the "reverberations of traumatic events endured by activists" (p. 24). By employing novel terminology, she seeks to capture nuances that extend beyond diagnosis. Similarly, Mann (2018) designates a new concept, "vystopia," to describe the existential despair experienced specifically by vegans as they come to terms with the massive scale of violence, secrecy, and denial surrounding animal agriculture and exploitation. Similar to Jones (2007), Mann (2018) suggests that trauma may arise in the symptomology of activism.

Unlike the previous authors, who concede that activists and vegans may experience adverse mental health symptoms yet express ambivalence about diagnosis, Joy (2018) emphasizes the prevalence of secondary traumatic stress (STS) among vegans. At the same time, she acknowledges the importance of relational context in the etiology of sTs, noting that painful experiences 
may become traumatic when vegans feel invalidated, betrayed, and invisible. Moreover, Joy (2011) uses the term "carnism" to describe the broader social context or violent ideological system in which vegans fail to thrive (p. 34). Carnism is a violent ideology that maintains normative societal practices of meat consumption through unchallenged beliefs and psychological defenses.

\section{Taxonomy of Trauma: From Intrapsychic to Trans-Species Trauma}

The term "trauma" has come under scrutiny in recent decades, as definitions of the concept shift and expand to allow us to better understand and legitimize the range of experiences that may fall under this umbrella. As such, it is important to differentiate between vernacular and diagnostic uses of the term, and to explore the overlapping intrapsychic, psychosocial, and cultural layers of trauma. While the symptoms of many activists may meet criteria for PTSD, it is not within the scope of this article to provide formal diagnosis but to point towards experiential trends within the community. The following conceptions inform this research, helping to frame the widening circles of intrapsychic, psychosocial, and interspecies trauma from which activists suffer.

While trauma can take many forms and arise in response to a variety of stimuli, contemporary trauma theorists agree that several criteria differentiate trauma from normal, stressful experiences: the experience of unbearable affect in response to an extraordinary or violent event, helplessness to change the outcome, and a lack of social or environmental support (van der Kolk, 2002; Levine, 2014; Herman, 2015). Trauma can range from simple to complex, and in its symptomatic severity (Briere \& Spinazzola, 2005).

Regardless of where an individual is on the continuum of trauma, symptoms may include all or some of the following: disassociation, flashbacks or persistent re-experiencing of the traumatic event, substance abuse, difficulty regulating anger, and mood disturbances (Levine, 2014; Stolorow, Atwood, \& Brandchaft, 1992; van der Kolk, 2002).

One way to characterize trauma is that it involves a sense of beyond-ness. Trauma is beyond that which an individual can tolerate, beyond that which they can name or describe, and beyond that which they can symbolize or understand. The raw, undigested sensory data of trauma remains embedded in the psyche, leading to a sense of timelessness (Van der Kolk, 2002) and silence (Lacan, 1977; Stolorow, Atwood, \& Orange, 2002) around the event. Rogers (2006) coins this silence "the unsayable" of trauma. Psychiatrist Bessel van der Kolk (2002) explains that "trauma imprints are stored as fragmented sensory and emotional traces, rather than being organized into a narrative by 
the higher brain's autobiographical self" (p. 6). Because it cannot be digested, trauma is often expressed through enactment, avoidance, and mechanical repetition (Levine, 2014). Reenactment, numbing, or avoidance can lead to altered cognitions about the self, others, or the world.

While trauma has a colloquial as well as diagnostic valence that can apply to animal rights activists, the work of activists can also trigger diagnosable PTSD. The Diagnostic and Statistical Manual of Mental Disorders (5th ed.; DSM-5) of the American Psychiatric Association (2013) requires that the following criteria are met for a diagnosis of PTSD:

Exposure to actual or threatened death, serious injury, or sexual violence in one (or more) of the following ways: (1) Directly experiencing the traumatic event(s), (2) Witnessing, in person, the event(s) as it occurred to others, (3) Learning that the traumatic event(s) occurred to a close family member or close friend, (4) Experiencing repeated or extreme exposure to aversive details of the traumatic event(s). (p. 271)

For the purpose of this article, we focus on the criteria of witnessing: interviewed activists witness injury, as well as threatened, imminent death, and/or actual death of nonhuman animals as part of their advocacy; they thus meet criteria for a PTSD diagnosis.

\section{Trans-Species Trauma}

Trans-species psychology is a newly established field based on the recognition that science uses a unitary model of brain, mind, behavior, and consciousness for humans and nonhumans alike (Bradshaw \& Watkins, 2006, 2009; Bradshaw \& Sapolosky, 2006), a fact that provides scientists the rationale for using nonhumans in lieu of humans in biomedical and other research (i.e., animal models; Bradshaw \& Sapolsky, 2006). As such, trans-species psychology recognizes the formal diagnosis of PTSD in wild African elephants, chimpanzees, parrots, and other nonhuman animals (Bradshaw et al., 2005; Bradshaw \& Schore, 2006; Bradshaw et al., 2008; Bradshaw, Capaldo, et al., 2009; Bradshaw, Yenkosky, et al., 2009). Given that trauma can result from witnessing death or harm to another, limbic and nervous systems of separate individuals must be closely entwined.

Limbic resonance is the sharing of deep emotional states with others, a capacity originating in the limbic system, the seat of emotions and memory (Lewis, Amini, \& Fannon, 2000). Lewis et al. (2000) attribute this capacity to all mammals and some birds, and theorize that it even crosses the species line through nonverbal cuing, allowing nonhumans to share affective states with humans, and vice versa. In the sharing and communicating of this neural substrate, it is natural for humans to feel connected to other animals. 
Moreover, it is not uncommon for those who devote themselves to work with animals to possess a trans-species identity, as Bradshaw et al. (2012) discovered among animal sanctuary workers. Those who possess this identity may identify as much with nonhuman animals as humans. Trans-species identity does not necessitate disidentification with humans but "merely a non-exclusionary, non-prejudicial attitude that transcends external form" (Bradshaw et al., 2O12, p. 10). While some may pathologize this identity, it is actually more reflective of scientific knowledge than a strictly anthropocentric identity. Indeed, those who have experienced cross-species fostering, such as human-raised chimpanzees or human children raised by wildlife, exhibit "bicultural" minds and identities which may not reflect their biological origins (Bradshaw, Capaldo, et al., 2009; Bradshaw, 2017). For those who embrace a trans-species identity, witnessing the suffering of nonhumans with whom they identify may activate even stronger neuroaffective responses. Alexander (2004) confirmed that groups that identify with traumatized others are more likely to experience their suffering as their own.

\section{Collective Trauma}

In addition to referring to subjects whose trauma is experienced vicariously, the intersubjective component of trauma includes the relationships and social contexts in which traumatized individuals are embedded. The absence or presence of a trusted individual to validate or make sense of a difficult experience can create or ameliorate, respectively, traumatic stress. While the relational component of trauma generally refers to early trauma in the context of caregiving, recent theorists have shown that the later failure of a parent, partner, or even community to recognize an experience as traumatic can determine the course of post-traumatic stress symptomatology (Herman, 2015; Joy, 2018; Rasmussen, 2005; Fierke, 2004).

Relational failure can be most easily perceived between individuals, but gaps in attunement stem from what is and is not permissible in the culture in which those individuals are embedded (Alexander, 2004; Fierke, 2004). Expanding the intersubjective lens to include the cultural and the political, Herman (2015) asserts,

The systematic study of psychological trauma therefore depends on the support of a political movement.... In the absence of strong political movements for human rights, the active process of bearing witness inevitably gives way to the active process of forgetting. (p. 9)

Cultural or collective trauma is a natural consequence of the essentially relational nature of trauma, wherein the ripples of trauma experienced by an 
individual or group multiply and extend to touch an entire group, society, or civilization. A characteristic of collective trauma, a term coined by Erikson (1976), is that it involves "a blow to the basic tissues of social life that damages the bonds attaching people together and impairs the prevailing sense of communality" (p. 154). While the designation of collective trauma has largely been used to describe the impact of widely documented violent events such as the Holocaust, it also refers to an ongoing practice that "works its way slowly and even insidiously into the awareness of those who suffer from it, so it does not have the quality of suddenness normally associated with 'trauma"' (p. 154).

An intersubjective understanding of trauma that includes the socio-cultural collective provides a framework for understanding the particularly deleterious effects of trauma within animal advocacy. For animal advocates and those bearing witness to animal suffering, the failure of regulation and emotional attunement takes place within society, institutions, discourse, and the law (Bryant, 2006). In other words, Western-industrial society's refusal to recognize and acknowledge the violence of animal agriculture, compounded with its denial and dismissal of advocates' powerful reactions against it, constitutes a massive relational failure.

\section{Voices from the Frontlines}

Pervasive traumatic experiences among activists directly relate to the events they witness and are exacerbated by immediate and broad social contexts. Symptoms include (a) Persistent re-experiencing of encounters, through dreams, flashbacks, or intrusive thoughts; (b) Dissociative responses: Feelings of being emptied out, speechless, invisible, numb, or psychically dead; (c) and Relational disturbance: Shifts in perception about themselves, their community, and the world, centered around the theme of betrayal. What follows is a summary of their experiences and documentation of the prevalence of common complaints.

One can assert that widespread atrocities in the history of humankind have been "enabled by a populace that turned away from a reality that seemed too painful to face, while virtually every revolution for peace and justice has been made possible by a group of people who chose to bear witness and demanded that others bear witness as well" (Joy, 2011, p. 185). Nine out of ten advocates made eye contact or shared extended gaze with nonhuman animals, in a direct attempt to acknowledge and share in sentience that is otherwise ignored $(\mathrm{P} 1$, $\left.\mathrm{P}_{2}, \mathrm{P}_{4}, \mathrm{P}_{5}, \mathrm{P} 6, \mathrm{P}_{7}, \mathrm{P} 8, \mathrm{P}_{9}, \mathrm{P}_{10}\right)$. Indeed, eye contact is the means through which two subjects achieve neural attunement, activating the limbic system of both 
parties, as well as the firing of mirror neurons in select species (Lewis et al., 2000). For these nine advocates, the attunement to animals in acute states of distress through gaze-sharing was deeply impactful, and the frequent subject of flashbacks and intrusive thoughts.

Interviewees reported a range of feelings in sharing gaze, from "pure guilt" $(\mathrm{P} 4)$ to "attempting to share comfort and compassion" $(\mathrm{P} 1)$ to "blind rage, wanting to kill the people who did this to them" (P6). Eight out of ten interviewees reported feelings of powerlessness and guilt in these interactions, and in being seen by animals whom they were not able to save $\left(\mathrm{P}_{1}, \mathrm{P}_{2}, \mathrm{P}_{4}, \mathrm{P}_{5}, \mathrm{P}_{7}, \mathrm{P}_{8}, \mathrm{P}_{9}\right.$, $\mathrm{P} 10)$. In attempting to serve as an antidote to the literal and metaphorical tendency to "look away," advocates find themselves holding a burden of emotional knowledge not shared by the wider populace.

Indeed, Joy (2003) documents a meat-eater who acknowledges benefitting from his distance from the deaths in which he is complicit: "I don't have to look at the cow's eyes while they're strangling it or whatever they do to a cow - shoot it? I can eat it, but I don't see myself actually killing anything" (p. 137). Five out of the ten interviewed activists reported feeling great frustration as they tried to get non-activists to view footage of their experiences $\left(\mathrm{P}_{2}, \mathrm{P}_{4}, \mathrm{P}_{7}, \mathrm{P} 8, \mathrm{P} 10\right)$. They received responses such as, "I don't want to look at it," or "nobody cares," or even anger from those who resented the emotional imposition.

The unrelenting reviviscence of industrial slaughter mimics the traumatized brain, whose tendency is to continually reexperience the traumatic moment (Levine, 2014; van der Kolk, 2002). As such, to "know" the reality of industrial slaughter is to form a traumatic cognition that can defend its own reviviscence. All activists reported symptoms of persistent reexperiencing, including flashbacks, nightmares, and intrusive thoughts. One activist recounts that, "A couple of weeks ago, every night I started imagining what it would be like to be facing slaughter, to be turned upside down like that, facing the knife - I don't even know where that came from ... it felt really scary" $\left(\mathrm{P}_{1}\right)$. Four activists reported having frequent nightmares, and five reported having what they later came to understand as flashbacks. One activist recounts: "One heavy impact of filming was to get intrusive repetitive images, all the time. It's PTSD but I didn't understand that then. When anything's heightened, bad or good, that imagery comes out of nowhere" (P6). Another recounts: "I would be sitting at a table doing outreach, and suddenly I was gone. I was going down the line, seeing the faces of pig after pig being slaughtered. They all had the eyes of the pig I saw at the last vigil" (P8).

Ten out of ten interviewed activists reported feelings of intense powerlessness, either over the recurrence of images, unexpected flashbacks, or over the possibility of effecting change within such a massive and well-defended 
system. Van der Kolk (2002) believes that feelings of powerlessness are one of the linchpins of trauma and can make the difference between a merely overwhelming experience and a traumatic one. Indeed, activists that were able to rescue animals and effect some change reported fewer lasting effects of trauma. Three out of the ten activists noted the difference between the impact of attending vigils and of attending open rescues; all of them reported greater feelings of empowerment and hope in response to the latter ( $\mathrm{P} 1, \mathrm{P} 6, \mathrm{P} 9)$.

Intrusive images or flashbacks are often accompanied by an overwhelming sense of powerlessness, guilt, and convictions of betraying or being betrayed. This combination of feelings is so intensive that four out of ten interviewees employed war metaphors ( $\left.\mathrm{P}_{3}, \mathrm{P}_{4}, \mathrm{P} 8, \mathrm{P} 9\right)$. $\mathrm{P}_{4}$ insists, "It's a war. I'm almost like a soldier at the frontlines," while P9 recounts, "I'm on the frontlines. Sometimes I wake up and cry the first thing, my hand, my jaw - clenching and fighting." In some cases, the sense of being a "soldier" led to desperate martyrdom verging on suicidality. One activist stated, "If I sacrifice a part of me for this, so be it. But sometimes I wonder, what am I doing to myself?" ( $\left.\mathrm{P}_{4}\right)$. After attending several consecutive vigils and trying to suppress their feelings, another advocate encountered a flood of emotions the next day and "was almost willing to escalate it to a level of martyrdom," noting "I want to lie in front of one of those trucks; I want to get run over, get shot, get arrested" (P8).

While only two of ten advocates mentioned suicidality, many interviewees reported symptoms of disassociation that felt like, "a part of me dying" (P1o). One explained that "Every time a cow got slaughtered, I died as well. A thousand times, I died" ( $\left.\mathrm{P}_{7}\right)$. Activists reported that they would experience periods of feeling like, "the walking dead" $\left(\mathrm{P}_{4}\right)$. When participating in an undercover investigation, one activist recounts that "The minute I walked in something turned off in me - there was a rooster impaled on a barb-wired fence. I just shut down. There was no emotion. I was done." Eight out of ten activists reported psychic deadening ( $\left.\mathrm{P}_{1}, \mathrm{P}_{3}, \mathrm{P}_{4}, \mathrm{P}_{5}, \mathrm{P}_{7}, \mathrm{P} 8, \mathrm{P}_{9}, \mathrm{P}_{10}\right)$, six of whom described themselves as shocked or surprised that they "felt nothing" when attending select vigils or events.

Five of these activists reported a flood of feelings returning at later points in their days or weeks $\left(\mathrm{P}_{1}, \mathrm{P}_{4}, \mathrm{P}_{5}, \mathrm{P}_{7}, \mathrm{P} 9\right)$, and five reported experiencing prolonged feelings of depression, burnout, or a lack of interest in continuing activism for a week or longer after experiencing a lack of feeling at the event $(\mathrm{P} 1$, $\left.\mathrm{P}_{4}, \mathrm{P}_{5}, \mathrm{P}_{7}, \mathrm{P}_{10}\right)$. Two out of ten activists reported living a "double life" $\left(\mathrm{P}_{1}, \mathrm{P}_{3}\right)$, wherein they occupied entirely different selves and personalities during their activist encounters and while at their traditional day jobs; this is a dissociative phenomenon known as "doubling" (Dillard, 2008).

While all respondents reported some form of disassociation, whether through psychic deadening, doubling, or depersonalization, symptoms of 
disassociation extend beyond the boundaries of the activists' psyches. This disassociation is a pervasive quality of the social-industrial context in which activist encounters occur. Systemic disassociation renders nonhuman suffering literally and rhetorically invisible (Bryant, 2006, p. 126). This societal disassociation is echoed on factory farms, where deaths are depersonalized through mechanization (Porcher, 2011), distancing language (referring to cows as "beef" even before they are killed), geographical concealment, and the division of labor that results in no individual worker feeling responsible for the animal's death (Pachirat, 2011). In this sense, feelings of emptiness and being of the "walking dead" arise in solidarity with nonhuman animals whose existence is reduced to flesh.

While emotional deadening is a symptom of trauma, it is also a defense against further traumatization. Psychic deadening immobilizes activists' emotional selves to protect them from intolerable co-suffering and the coexperience of annihilation. While silence and deadening are entangled responses to this co-suffering, they are also features of becoming one of the unseen - the potent, sensory-emotional communication with the animals is unacknowledged, and with this connection, the very reality of shared affective experience is ignored.

Activists co-experience traumatic symptoms of speechlessness, emptiness, and becoming flesh, both through intersubjective attunement and within their own parallel processes (Fierke, 2004; Grotstein, 1990; Kirshner, 1994; van der Kolk, 2002). Pachirat (2011) finds a careful division between what is speakable and unspeakable in the slaughterhouse, and meets a great silence when he describes Temple Grandin's attempts to reduce stress in cows approaching slaughter. This silence illustrates that the "gap between evaluation and what defies quantification in the actual work, particularly affection and the moral sense, is not something workers discuss amongst themselves: it is unspeakable" (Porcher, 2011, p. 11).

For activist and slaughterhouse vigil attendee $\mathrm{P} 1$, wordlessness is common: "I feel voicelessness all of the time. I can remember driving back from some of the vigils, with a car full of people, just very silent ... just you know ... what is there to say." When $\mathrm{P} 2$ attempts to describe a slaughterhouse raid to someone he runs into at the grocery store, he also finds himself without words: "I just turned around and left. I couldn't say anything about [the raid]. I just felt like I was going to break down. I was tongue-tied ... I couldn't put words to the experience." After attending vigils and slaughterhouse raids, $\mathrm{P}_{5}$ says, through tears, "Five years ago I feel like I was much more energetic, lively, and youthful ... ideas bursting out of my head. Now, I don't really want to talk."

The experience of trauma is "whereof we cannot speak" (Fierke, 2004, p. 479). The "unsayability" (Rogers, 2006) of trauma is as much about that 
which is beyond symbolization as it is the societal impermissibility of naming that which occurred, thus excluding the trauma from the social construct of language (Fierke, 2004). Activists are co-silenced as they witness animals stripped of their voices. They enter into the flanks of the unheard when others disavow and suppress what they have witnessed. Activists often receive negative responses, such as "I don't want to hear about it" (Bradshaw, 2019) or "I don't want to watch" ( $\left.\mathrm{P}_{2}\right)$ from those with whom they try to share their experiences. Friends, family, and coworkers "either turn away and won't watch the video evidence, or even blame you for trying to show them this uncomfortable truth" (P10). Others experience harassment by federal officers, trouble with the law, and threats designed to keep them silent $\left(\mathrm{P}_{2}, \mathrm{P}_{7}, \mathrm{P}_{9}, \mathrm{P}_{10}\right)$.

\section{The Great Betrayal}

Common symptoms noted in the aforementioned data, namely speechlessness, suicidal ideation, psychic deadness, and persistent reexperiencing, are symbols of societal alienation, self-contained pleas, and loops lacking social outlets. These symptoms are aborted attempts to communicate with the self and others, robbed of the means by which to do so: through speech, emotional aliveness, wholeness, and availability for new experiences.

How do activist-witnesses process overwhelming affect and trauma inside of a broken container, within the same system that allowed traumatic violations to occur? Edkins (2003) contends that trauma involves a feeling of betrayal by those on whom one relies, even by those not directly involved. When the aforementioned data are analyzed within a relational framework, symptoms suggest complex relational betrayal. Interviewed activists witness traumatic events among those who perpetrate them and authorities who persecute activists for their engagement. They return home to families or communities who may blame them for their suffering, refuse to validate what they have seen, or remain unsympathetic or removed from their cause.

Activists expressed feeling betrayed by multiple social actors who demand and disavow the conditions for their traumatic suffering, including those who consume meat, benefitting at a distance. One activist recounts thinking that "If I heard one more person give me an excuse about why they couldn't go vegan, I felt like I was going to explode. I started to drink heavily" $\left(\mathrm{P}_{3}\right)$. Another activist attempted to confide in family members about the severe PTSD she experienced after undercover investigations. Her family responded by stating, "It's your fault for putting yourself in those spots" (P8). Even when activists are provisionally accepted into non-vegan social groups, they may feel alone. $\mathrm{P}_{4}$ laments that while his coworkers support his work in theory, they are unwilling to watch the videos he produces or reconsider their consumption of meat. 
Activists' trust in family members, non-vegans, and in humanity in general tended to be forever altered by their encounters. Three activists $\left(\mathrm{P}_{1}, \mathrm{P}_{4}, \mathrm{P} 8\right)$ note that while they used to enjoy going out and connecting with friends, they have "lost interest in interacting with others" $\left(\mathrm{P}_{4}\right)$. Seven out of ten shared that they did not have any non-vegan friends $\left(\mathrm{P}_{2}, \mathrm{P}_{3}, \mathrm{P}_{5}, \mathrm{P} 6, \mathrm{P} 8, \mathrm{P} 9, \mathrm{P} 10\right)$. One divulges, “I don't trust people, I don't respect them. I don't think they're guided by any kind of reality. I look at [non-vegans] and think, 'you and I aren't even the same species'" (P8). Activists may feel betrayed in a primal sense by reality itself, and their sense of what is good and meaningful by widening circles of indifference: "It can sometimes get me really down and really abysmal about society and the world in general" (P6).

Four out of ten activists $\left(\mathrm{P}_{2}, \mathrm{P}_{3}, \mathrm{P} 6, \mathrm{P} 8\right)$ reported feeling unsafe even around other activists, who criticized them for being "too emotional" ( $\left.\mathrm{P}_{2}\right)$ and continually urged them to "keep their feelings in check" (P6). One noted that in her vegan community, people valued "strength," which they viewed as "not losing it or being too emotional" ( $\mathrm{P} 10)$. Three felt plagued by constant infighting ( $\mathrm{P}_{3}$, $\mathrm{P} 6$, P8). Emphasis among vegans on reducing emotionality may represent selfcritical collusion with widespread psychic numbing around animal agriculture and conceptions of vegans as "hysterical" (Joy, 2018).

Eight out of the ten activists reported feeling that they themselves were guilty of betrayal $\left(\mathrm{P}_{1}, \mathrm{P}_{2}, \mathrm{P}_{4}, \mathrm{P}_{5}, \mathrm{P}_{7}, \mathrm{P} 8, \mathrm{P}_{9}, \mathrm{P}_{10}\right)$. One activist shares her mixed feelings about sharing gaze with an animal:

My intention was just to be as calm as I could, just sending as much love as I could; wanting to delay the inevitable for them. But then it's almost like a betrayal to them because if they were to believe that ... I'm not getting them out of there. $(\mathrm{Pl})$

Another shared that, when meeting the animals' eyes, "I felt so powerless. 'I'm leaving you here, and that's my fault.' And that destroyed me. It still does" ( $\left.\mathrm{P}_{5}\right)$.

When an activist returns home from a vigil, open rescue, or undercover investigation, the "traumatic experience creates a gap and discontinuity between the survivor and the ones to whom he returns" (Bradshaw, 2009, p. 120). Similar to veterans who return deeply changed to an unchanged home, activists return to a reality that continues to buzz with business as usual (Bradshaw, 2017). Only this bright, bustling world silently constellates around the nightmare world from which they just returned. Its industries, rituals, garments, and economy rely on the death of nonhumans whose gaze these activists just shared: "I see it everywhere. I'm afraid to go outside. Someone wearing 
leather. Someone eating a chicken sandwich. It takes me right back. It's maddening" ( $\left.\mathrm{P}_{2}\right)$.

Indeed, this social world is itself a subject that both sparks and fails to mediate trans-species trauma. If trauma is a socially mediated attribution, one characterized or exacerbated by the failure of others to contain, validate, or attune (Stolorow, Atwood, \& Brandchaft, 1992; van der Kolk, 2002), animal activist trauma reverberates in a cultural echo chamber.

\section{Healing the Collective}

Characterizations of animal activists as extremists, cult members, hysterical, overly emotional, radical, or judgmental commonly cultivate a feeling of alienation and rejection by a society that perpetuates the suffering on which their extreme reactions are based. While animal activists suffer frequent pathologization in social discourse, I argue that their (widely trauma-based) symptoms are in fact "healing pathologies," designed to bring attention to what seeks healing in the collective. Alexander (2004) believes cultural trauma occurs when:

social groups ... and sometimes even entire civilizations not only cognitively identify the existence and source of human suffering but 'take on board' some significant responsibility for it.... Is the suffering of others also our own? In thinking that it might in fact be, societies expand the circle of the we. (p. 13)

However, he also notes that,

By the same token, social groups can, and often do, refuse to recognize the existence of others' trauma ... by refusing to participate in what I will describe as the process of trauma creation, social groups restrict solidarity, leaving others to suffer alone. (p. 13)

For perpetrators of, or bystanders to, violence, collective trauma can pose an "identity threat" (Hirschberger, 2018). Acknowledgment of responsibility for trauma is inconsistent with perpetrators' desires to see themselves as moral agents. This wounding at the core of the group must be protected, deflected, and projected in order to maintain functioning and a sense of cultural coherence, and potentially to shield the group from annihilation or disintegration into anxiety, guilt, or deep grief. They may seek to reconstruct events in a more palatable manner or in a way that reduces collective responsibility. When this 
is not possible, perpetrators or bystanders may resort to denial, dismissal, or silence, "creating an uncomfortable gap in collective memory - an absence suggesting a presence" (Alexander, 2004, p. 53).

These gaps in cultural memory and discourse result in "hauntings," a term Inouye (2016) used to describe suppressed traumatic memories that persist across generations and eventually rupture the veil of silence through collective actions. Those who bring forward the hauntings of collective trauma are designated the "carrier group," a group that carries the burden of the trauma and brings public attention to its impact and importance within society (Alexander, 2004).

I emphasize that while collective silences may temporarily mute collective trauma, the silences themselves point to a powerful presence. Recall that Rogers (2006) conceived of unprocessed trauma as a silent "unsayable" around which unconscious behaviors and defenses recurrently constellate. Similarly, unprocessed collective trauma is evident in what is most vehemently denied, silenced, and defended against within society. Herman (2015) confirmed that "repression, disassociation and denial are phenomena of social as well as individual consciousness" (p. 9). Animal activists seek to disrupt this carefully constructed cultural complex, one designed to maintain collective silence. In pushing against this veritable wall of silence, they bear the emotional brunt for all.

\section{Trans-Species Collective Trauma}

According to the aforementioned conceptualizations of collective trauma, Western-industrial society is deeply in its grips. The massive scale of violence against nonhumans, perpetrated, condoned, or partaken in by the vast majority of human community members, speaks to a collective rupture at the heart of society and operates as a "haunting" or "unsayable" around which much of social life constellates. Multiple social forces "restrict solidarity" with animals designated as commodities, leaving them to "suffer alone" (Alexander, 2004, p. 45). Those who are complicit must continually silence and defend against knowledge of nonhuman suffering, lest they experience "identity threat," along with deep guilt, grief, and co-experiences of trauma.

Because neuroscientists and the public concur that the human psyche is continuous with that of the nonhuman (Bradshaw \& Watkins, 2006), it is fair to say that violent ruptures in the bonds between humans and nonhumans damage the tissues of the entire social fabric. The maintenance of this violence is enacted through the centuries old, well-documented ideology of the 
human-animal split (Derrida, 2008; Regan \& Singer, 1989), a categorical divide that situates nonhuman animals as other than and inferior to human beings.

While it is not difficult to observe the devastating impact of this split for nonhumans, the insidious nature of the traumatic rupture between humans and nonhumans is slowly working its way into human consciousness, particularly through the mental health of animal rights activists. This complex alienates humans from nonhuman animals and nature, and thus from the very ground of their being. If, as Jung notes, "the collective unconscious is ... the 'animal' ... level of the psyche" and "Everything stated or manifested by the psyche is an expression of the nature of things, whereof man is a part" (Adler, 1975, para. 540), what are the costs of severing this primal connection?

The tension between this burgeoning awareness and ubiquitous violence and objectification of nonhumans requires massive psychological defenses. These defenses are forms of "hauntings" that point to collective trauma in the very rigor of their implementation. These social defenses include social discourse meant to numb affect and reduce empathy and relationality, such as referring to pigs as "pork," removal of slaughterhouses from the public eye, disidentifying meat from lived referents, and, most saliently, the literal silencing of activist-witnesses through Ag-Gag laws and the Animal Enterprise Act. Indeed, two interviewed activists reported trauma symptoms stemming from prolonged persecution by federal agents $(\mathrm{P} 4, \mathrm{P} 8)$. If governmental entities go to such great lengths to prevent the public from witnessing nonhuman suffering, these gatekeepers must believe that the reinstatement of connection may cause deep ripples of change.

While the forces of silencing and denial are powerful, Inouye (2016) notes that which is silenced tends to persist across space and time, and if it is not (or cannot be) taken up by those directly impacted, a carrier group brings this trauma forward into the collective. In their willingness to experience nonhuman suffering as their own, interviewed activists become the carrier group for collective trans-species trauma. In their co-experience of nonhuman suffering, activists reinstate the human-animal continuum, and through their symptoms, they point to what seeks healing and integration.

By virtue of their scientifically supported willingness to include nonhumans in their "expanded circle of we" (Alexander, 2004), activists express symptoms for animals who are precluded from speaking for themselves, taking "on board" nonhuman suffering as their own. At the same time, activist trauma, ranging from disassociation to heightened emotionality, is a symptom of a cultural dysfunction.

A symptom is an unwelcome harbinger of truth beginning to emerge from that which has been ignored or denied. Freud (1920) noted that patients often experienced their psychological symptoms as alien to their conscious selves 
and personalities and employed psychological defenses to disidentify from them. But it was necessary for these patients to acknowledge and affirm these systems in order to heal, for they pointed to systemic dysfunction. Hillman (1975) viewed symptoms as sacred impetuses towards healing, and Jung (1969) claimed that they "help give expression to the unrecognized side of the psyche" (para. 328) or the unconscious. As willing symptom-bearers for the Western-industrial cultural body, activists give expression to collective trauma within the cultural unconscious. While the larger social body disidentifies with activist symptom-bearers through pathologization, distancing, denial, and aggression (Kymlicka, 2019; Mann, 2018), the strength of these corresponding defenses only serves to reaffirm the presence of wounding at the collective core.

When understood in this way, pervasive activist trauma and associated fervent advocacy pierce the veil of collective silence and "feel" for a society defended against collective trauma. Indeed, the pain that activist-witnesses experience is a natural consequence of acknowledging kinship with a group that suffers unremitting violence. Unfortunately, traumatized activists may not always be able to "feel" effectively or at all, and thus cannot help the collective to reinstate its feeling function with regard to nonhumans. Therefore, I argue that it is vital to depathologize activist suffering, because trauma can only continue to manifest itself within a social context of alienation and disavowal (Fierke, 2004). Recall that trauma is a socially mediated attribution and it becomes frozen, persistently reexperienced, and emptied of speech in part because it is excluded from social discourse. As the culture fails to mourn nonhumans deemed commodities, activist grief becomes encoded as trauma to the extent that it is embedded in a defended, psychically frozen collective.

Activists who choose to bear witness, and suffer trauma as a consequence, illuminate a darkened corner of collective awareness. When the deep multispecies pain of activist encounters is culturally validated, activist trauma can relax into grief. As forerunners of a paradigm shift that acknowledges human continuity and kinship with nonhuman animals, they model what is necessary for collective healing: the willingness to suffer (Joy, 2018).

The antidote to collective freezing and defensive silencing is collective witnessing, and with it the acknowledgement of continuity with animals deemed commodities. This acknowledgement would entail working through existential "identity threats," reformulating cultural narratives, and processing collective guilt, grief, and trauma. When activists are honored as symptom-bearers and their affect-laden stories respectfully received, their trauma may become the voice for collective grief, and through this grief, the vehicle for collective, trans-species healing. 


\section{References}

Adler, G. (Ed.). (1975). C. G. Jung letters I and II. Princeton, NJ: Princeton University Press.

Alexander, J. C. (2004). Towards a theory of cultural trauma. In J. C. Alexander (Ed.), Cultural trauma and collective identity. Berkeley, CA: University of California Press.

Alford,C.F.(2018).Traumaand psychoanalysis:Freud,Bion, andMitchell.Psychoanalysis, Culture \& Society, 23(1), 43-53. https://doi.org/10.1057/s41282-018-0070-7.

American Psychiatric Association. (2013). Trauma- and stressor-related disorders. In Diagnostic and statistical manual of mental disorders (5th ed.). https://doi.org/ 10.1176/appi.books.9780890425596.dsmo7.

Bradshaw, G. A. (2009). Elephants on the edge: What animals teach us about humanity. New Haven, CT: Yale University Press.

Bradshaw, G. A. (2017). Carnivore minds. Who these fearsome animals really are. New Haven, CT: Yale University Press.

Bradshaw, G. A. (2019). Nonhuman animal accompaniment. In Accompaniment (M. Watkins, Ed.). New Haven, CT: Yale University Press.

Bradshaw, G. A., \& Sapolsky, R. N. (2006). Mirror, mirror. American Scientist, 94(6), 487-489.

Bradshaw, G. A., \& Watkins, M. (2006). Transpecies psychology: Theory and praxis. Psyche and Nature, 75, 69-94.

Bradshaw, G. A., Borchers, J. G., \& Muller-Paisner, v. (2012). Caring for the caregiver: Analysis and assessment of animal care professional and organizational wellbeing. The Kerulos Center.

Bradshaw, G. A., Capaldo, T., Lindner, L., \& Grow, G. (2008). Building an inner sanctuary: Trauma-induced symptoms in non-human great apes. Journal of Trauma and Dissociation, 9(1), 9-34.

Bradshaw, G. A., Capaldo, T., Lindner, L., \& Grow, G. (2009). Developmental context effects on bicultural post-trauma self repair in Chimpanzees. Developmental Psychology, 45, 1376-1388.

Bradshaw, G. A., Schore, A. N., Brown, J., Poole, J., \& Moss, C. J. (2005). Elephant breakdown. Nature, 433, 807 .

Bradshaw, G. A., Yenkosky, J., \& McCarthy, E. (2009). Avian affective dysregulation: Psychiatric models and treatment for parrots in captivity. Proceedings of the Association of Avian Veterinarians: 28th Annual Conference, Minnesota.

Briere, J., \& Spinazzola, J. (2005). Phenomenology and psychological assessment of complex posttraumatic states. Journal of Traumatic Stress, 18(5), 401-412.

Bryant, T. L. (2006). Trauma, law and advocacy for animals. Journal of Animal Law \& Ethics, 1, 63-138. 
Derrida, J. (2008). The animal that therefore I am. New York, NY: Fordham University Press.

Dillard, J. (2008). A slaughterhouse nightmare: Psychological harm suffered by slaughterhouse employees and the possibility of redress through legal reform. Georgetown Journal on Poverty, Law, and Policy, 15, 391-408.

Edkins, J. (2003). Trauma and the memory of politics. Cambridge, England: Cambridge University Press.

Erikson, K. (1976). Everything in its path: Destruction of community in the Buffalo Creek flood. New York, NY: Simon \& Schuster.

Fierke, K. M. (2004). Whereof we can speak, thereof we must not be silent: Trauma, political solipsism and war. Review of International Studies, 30(4), 471-491.

Freud, S. (1920). A general introduction to psychoanalysis. Createspace Independent Publishing Platform.

Goldsmith, R. E., Barlow, M. R., \& Freyd, J. J. (2004). Knowing and not knowing about trauma: Implications for therapy. Psychotherapy: Theory, Research, Practice, Training, $41(4), 448$.

Hawthorne, M. (2018). Striking at the roots: A practical guide to animal activism. Winchester, UK: Changemakers Books.

Herman, J. L. (2015). Trauma and recovery: The aftermath of violence - from domestic abuse to political terror. New York, NY: Basic Books.

Hillman, J. (1975). Re-visioning psychology. New York, NY: Harper Collins.

Hirschberger, G. (2018). Collective trauma and the social construction of meaning. Frontiers in Psychology, 9. https://doi.org/10.3389/fpsyg.2018.01441.

Inouye, K. M. (2016). The long afterlife of Nikkei wartime incarceration. Stanford, CA: Stanford University Press.

Jones, P. (2007). Aftershock: Confronting trauma in a violent world. New York, NY: Lantern Books.

Joy, M. (2003). Psychic numbing and meat consumption: The psychology of carnism (Publication No. 7299468o7; Doctoral Dissertation). Saybrook Graduate School and Research Center. Proquest Dissertations Publishing.

Joy, M. (2011). Why we love dogs, eat pigs, and wear cows: An introduction to carnism. San Francisco, CA: Conari.

Joy, M. (2018). Beyond beliefs. Brooklyn, NY: Lantern Books.

Jung, C. G. (1969). The structure and dynamics of the psyche (R. F. C. Hull, Trans.). In H. Read et al. (Series Eds.), The collected works of C. G. Jung. Princeton, NJ: Princeton University Press.

Kalsched, D. (2014). The inner world of trauma: Archetypal defences of the personal spirit. London, England: Routledge.

Kirshner, L. A. (1994). Trauma, the good object, and the symbolic: A theoretical integration. The International Journal of Psychoanalysis, 75(2), 235-242. 
Kymlicka, W. (2019, April 30). Human supremacism: Why are animal rights activists still the "orphans of the left"? Retrieved from https://www.newstatesman.com.

Lacan, J. (1977). Écrits: A selection (A. Sheridan, Trans.). London, England: Tavistock.

Levine, H. B. (2014). Psychoanalysis and trauma. Psychoanalytic Inquiry, 34(3), 214-224. https://doi.org/10.1080/o7351690.2014.889475.

Lewis, T., Amini, F., \& Lannon, R. (2000). A general theory of love. New York, NY: Random House.

Lockwood, A. (2018). Bodily encounter, bearing witness and the engaged activism of the Global Save Movement. Animal Studies Journal, 7(1), 104-126.

Mann, C. (2018). Vystopia: The anguish of being vegan in a non-vegan world. Sydney, Australia: Communicate 31 Pty Ltd.

Oliver, K. (2001). Witnessing: Beyond recognition. Minneapolis, MN: University of Minnesota Press.

Oliver, K. (2004). The colonization of psychic space: A psychoanalytic social theory of oppression. Minneapolis, MN: University of Minnesota Press.

Pachirat, T. (2011). Every twelve seconds: Industrialized slaughter and the politics of sight. New Haven, CT: Yale University Press.

Porcher, J. (2011). The relationship between workers and animals in the pork industry: A shared suffering. Journal of Agricultural and Environmental Ethics, 24(1), 3-17.

Rank, M., Zaparanick, T., \& Gentry, E. (2009). Nonhuman-animal care compassion fatigue. Best Practices in Mental Health, 2, 40-61.

Rasmussen, B. (2005). An intersubjective perspective on vicarious trauma and its impact on the clinical process. Journal of Social Work Practice, 19(1), 19-30. https:// doi.org/10.1080/02650530500071829.

Regan, T., \& Singer, P. (Eds.). (1989). Animal rights and human obligations. New York, NY: Prentice Hall.

Rogers, A. G. (2006). The unsayable: The hidden language of trauma. New York, NY: Random House.

Stolorow, R. D., Atwood, G. E., \& Orange, D. M.(2002). Worlds of experience:Interweaving philosophical and clinical dimensions in psychoanalysis. New York, NY: Basic Books. Van der Kolk, B. A. (2002). In terror's grip: Healing the ravages of trauma. Cerebrum, $4(1), 34-5$ o. 